\title{
Using large-scale citizen science ringing data as a means of calculating maximum longevity in birds
}

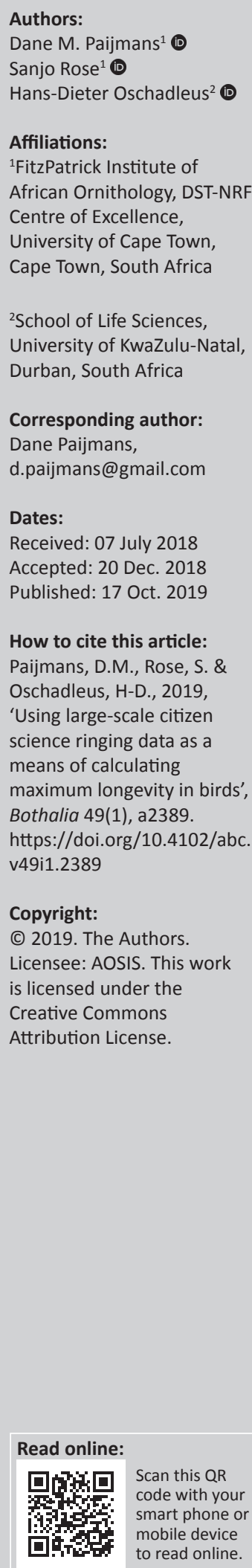

This article calculates estimates of avian longevity for southern African Passeriformes and demonstrates the impact citizen scientists have on data volumes curated by the South African Bird Ringing Unit (SAFRING). We calculated taxon-specific longevity records for 341 species from 33 families using ringing data collected between 1948 and 2017. An increase in active ringer participation over time correlated positively with an increase in retrap and recovery data, allowing for more reliable longevity calculations. These results highlight the significant contribution citizen scientists have made to bird ringing in southern Africa and identify datadeficient taxa to which future ringing activities should be targeted.

Keywords: SAFRING; banding; Passeriformes; Passerine; senescence; lifespan; age.

\section{Introduction}

Measures of longevity (i.e. maximum lifespan) are important for estimating a species' survival and persistence (Wasser \& Sherman 2010). As survival and recruitment are often difficult to calculate, longevity measures can provide an alternative means of estimating these values. Furthermore, for small birds, longevity indirectly gives a reasonable measure of fecundity as these species reach sexual maturity at an early age (Rising \& Bonan 2017).

Citizen scientists are informed and trained members of the public who devote their own resources to a scientific study while not necessarily having any formal scientific training (Haklay 2013). This contribution can improve the quality of research by allowing for greater sampling over larger geographic ranges and timescales. A well-established field of citizen science is bird ringing, where trained volunteers fit rings or tags onto birds for future identification. This is a reliable method of quantifying survival, senescence, recruitment and dispersal of wild birds (Baillie 2001; Robinson, Julliard \& Saracco 2009), and is an effective means of estimating longevity.

Bird ringing was started in southern Africa in 1948 by the South African Ornithological Society, later known as the South African Bird Ringing Unit (SAFRING) (Elliott 1971). The South African Bird Ringing Unit manages over 2.6 million ringing records from over 200 active ringers producing over 80000 records annually across southern Africa (Paijmans, Catto \& Oschadleus 2017). In this study, we aim to understand the impact citizen science has on the data volumes and accuracy of bird longevity estimates in the Order Passeriformes and produce an updated list of speciesspecific longevity records. Passeriformes have a large global geographic distribution consisting of 6456 species, of which 662 occur in southern Africa (BirdLife International 2017; Gill \& Donsker 2016). As many Passeriformes have a close relationship to humans (Lever 2010; Rising \& Bonan 2017), they are an ideal order for studies by citizen scientists.

\section{Methods}

The South African Bird Ringing Unit digitises all reported resightings, recaptures and recoveries of birds ringed with SAFRING rings, as well as foreign rings reported in Africa. Records (i.e. initial ringing, recapture, resighting and recovery) of southern African Passeriformes were extracted from this database in March 2018, along with the numbers and details of active ringers (i.e. those that ringed at least one Passeriformes in a given year). Using counts of active ringers per year, we assessed trends in annual ringing effort from 1948 to 2017 and plotted their distribution.

We used correlation analyses to determine how the number of active ringers influenced the total ringing output (i.e. number of birds ringed or recaptured in a year). The reporting rate, that is, the percentage of initial birds ringed that were subsequently reported, was calculated for each family. 
Longevity records were calculated for all species where both initial and reported records were available. Longevity was calculated as the maximum time lapsed (days and years) between the date of the initial ringing record and the final date on which the bird was either retrapped or recovered. Consequently, longevity values are minimum values. The longevity records were verified by the original reports submitted to SAFRING. Records noted as only 'rings found' or 'well-decomposed carcass found' were omitted from longevity reports owing to ambiguity of date of death. In instances where birds recovered in southern Africa had been ringed elsewhere, the initial record data for those individuals were sourced from the relevant ringing schemes. Retrap and recovery records were also compared by calculating ages at first ringing, percentages of records related to ringers and apparent causes of death.

Occasionally, rings start to wear and are thus replaced (or a new ring is added). In these cases, all ring numbers put on an individual bird are listed for longevity records.

\section{Ethical considerations}

This article followed all ethical standards for research without direct contact with human or animal subjects.

\section{Results}

A total of 1810199 records (1 678397 initial, 123922 retraps and/or resightings and 7880 recoveries) were reported for the Order Passeriformes (Table 1) by 872 active ringers across southern Africa (Figure 1) between 1948 and 2017. In that period, there was an increasing trend in the number of active ringers per year (slope $=2.72$ active ringers per year) (Figure 2a). On average, $16.03 \pm 8.93$ new ringers registered each year. Most of the registered Passeriformes ringers were citizen scientists, and many of those ringing professionally also ringed recreationally. Similarly, there was an increasing trend in the number of initial (slope $=888.35$ initial records per year) and subsequent (slope $=194.55$ subsequent records per year) ring records per year (Figure 2a). The increase in active ringers had a positive correlation to the number of initial (slope $=340.11$ initial records per active ringer, $R^{2}=$ $0.93, p<0.001$ ) and subsequent (slope $=66.73$ subsequent records per active ringer, $R^{2}=0.86, p<0.001$ ) records per year (Figure 2b).

The number of initial records was positively correlated with the number of retrap records (slope $=0.034$ retraps per

TABLE 1: Maximum longevity records curated by the South African Bird Ringing Unit for each of the southern African Passeriformes families.

\begin{tabular}{|c|c|c|c|c|}
\hline Family & Species count & Longevity (years, months, days) & $\mathbf{R R}$ & Records (initial, retrap and/or sighting, recovery, total) \\
\hline Ploceidae (weavers, widowbirds) & 27 & 7847 (21y $5 m$ 23d) & 4.5 & $(574433,23878,2141,600452)$ \\
\hline Sturnidae (starlings, rhabdornis) & 14 & 6935 (18y 11m 26d) & 4.6 & $(21967,686,321,22974)$ \\
\hline Pycnonotidae (bulbuls) & 9 & 6378 (17y $5 \mathrm{~m} \mathrm{16d)}$ & 8.2 & $(68575,5254,374,74203)$ \\
\hline Muscicapidae (chats, Old World Flycatchers) & 41 & $6374(17 y 5 m 12 d)$ & 16.5 & $(55$ 260, 8799, 337, 64 396) \\
\hline Turdidae (thrushes) & 3 & 5872 (16y 0m 28d) & 11.7 & (23 196, 2379, 340, 25 915) \\
\hline Malaconotidae (bushshrikes) & 23 & 5860 (16y 0m 16d) & 8.6 & (12 902, 1044, 61, 14 007) \\
\hline Promeropidae (sugarbirds) & 2 & 5340 (14y 7m 14d) & 11.2 & $(12325,1332,50,13$ 707) \\
\hline Sylviidae (sylviid babblers) & 32 & 4808 (13y $1 \mathrm{~m} 29 \mathrm{~d})$ & 12.3 & (73 301, 8918, 109, 82 328) \\
\hline Platysteiridae (wattle-eyes, batises) & 6 & 4787 (13y 1m 9d) & 7.4 & $(5154,371,11,5536)$ \\
\hline Motacillidae (wagtails, pipits) & 11 & $4760(13 y 0 m 12 d)$ & 5.7 & (13 244, 658, 94, 13 996) \\
\hline Estrildidae (waxbills, munias and allies) & 24 & 4624 (12y 7m 27d) & 9.9 & (158 228, 15 293, 382, 173 903) \\
\hline Passeridae (Old World Sparrows, snowfinches) & 6 & $4622(12 y 7 m 24 d)$ & 19.9 & $(117732,21954,1527,141$ 213) \\
\hline Laniidae (shrikes) & 5 & 4597 (12y 7m 2d) & 10.4 & $(10699,1018,100,11817)$ \\
\hline Dicruridae (drongos) & 2 & 4431 (12y 1m 18d) & 5.7 & $(2954,152,15,3121)$ \\
\hline Fringillidae (finches) & 14 & 4243 (11y 7m 13d) & 9.4 & (44 252, 4041, 101, 48 394) \\
\hline Hirundinidae (swallows, martins) & 17 & 4055 (11y 1m 6d) & 3.0 & $(239505,5858,1273,246636)$ \\
\hline Zosteropidae (white-eyes) & 3 & 3968 (10y $10 m$ 9d) & 9.4 & $(82417,7486,242,90145)$ \\
\hline Cisticolidae (cisticolas and allies) & 33 & 3796 (10y 4m 20d) & 16.6 & $(49021,8041,97,57$ 159) \\
\hline Paridae (tits, chickadees) & 6 & 3787 (10y 4m 12d) & 8.6 & $(1968,166,4,2138)$ \\
\hline Corvidae (crows, jays) & 2 & 3421 (9y 4m 13d) & 8.9 & $(191,5,12,208)$ \\
\hline Monarchidae (monarchs) & 2 & 3397 (9y 3m 19d) & 5.6 & $(3492,188,9,3689)$ \\
\hline Emberizidae (buntings and allies) & 5 & 3266 (8y 11m 8d) & 2.2 & $(27293,584,15,27892)$ \\
\hline Leiothrichidae (babblers) & 4 & 3018 (8y 3m 4d) & 11.4 & $(3063,331,18,3412)$ \\
\hline Eurylaimidae (broadbills) & 1 & 2986 (8y 2m 2d) & 18 & $(161,27,2,190)$ \\
\hline Viduidae (indigobirds, whydahs) & 7 & 2887 (7y 10m 26d) & 4.3 & $(11474,459,40,11973)$ \\
\hline Oriolidae (figbirds, orioles) & 3 & 1955 (5y 4m 5d) & 5.9 & $(1071,55,8,1134)$ \\
\hline Coraciidae (rollers) & 2 & 1561 (4y 3m 8d) & 3.5 & $(1157,34,6,1197)$ \\
\hline Remizidae (penduline tits) & 1 & 1031 (2y 9m 28d) & 25.8 & $(426,108,2,536)$ \\
\hline Chaetopidae (rock-jumper) & 1 & 400 (1y $1 \mathrm{~m} 4 \mathrm{~d})$ & 11.3 & $(133,15,0,148)$ \\
\hline
\end{tabular}

Note: Species count is the number of species for the family in southern Africa.

$\mathrm{RR}$, reporting rate $(\%)$. 
initial records) and recovery records (slope $=0.0043$ recoveries per initial records) for each species (Figure $3 a, b$, Appendix 1). This indicates that species with a greater initial ringing effort were more likely to be resampled. Species that did not conform to this pattern were the: Sociable Weaver (Philetairus socius) - 17870 initial records, 10399 retraps and 770 recoveries; White-browed SparrowWeaver (Plocepasser mahali) - 8793 initial records, 6759 retraps and 46 recoveries; Red-billed Quelea (Quelea quelea) - 149838 initial records, 286 retraps and 551 recoveries; and the Barn Swallow (Hirundo rustica) - 185047 initial records, 1189 retraps and 898 recoveries (Figure 3a, 3b). These outlier species were part of intensive and coordinated studies undertaken by professional researchers (Underhill, Oatley \& Berruti 1995) and subject to greater initial and/or

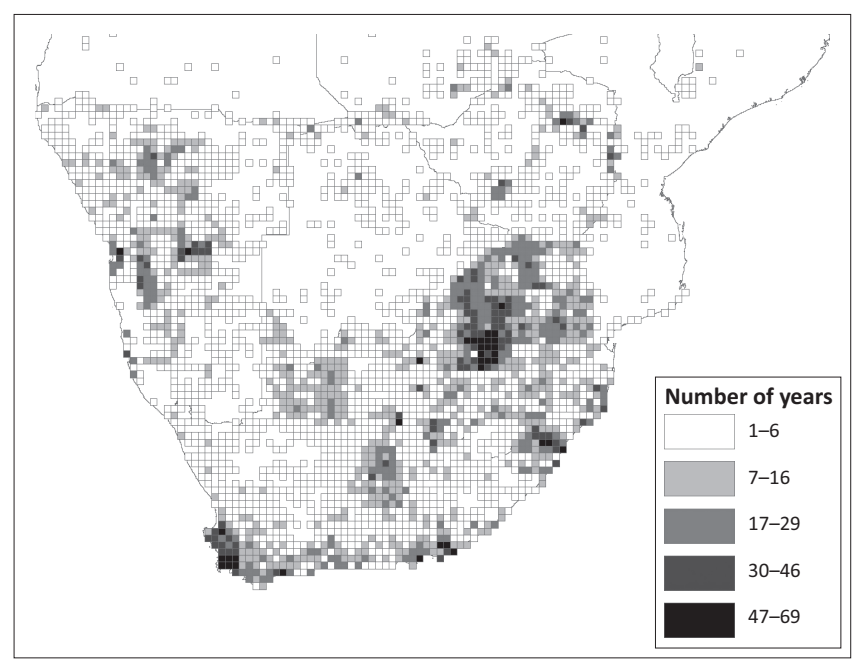

FIGURE 1: Distribution of ringing effort across southern Africa. The quarter degree cells are shaded according to the number of calendar years that ringers were active between 1948 and 2017. subsequent trapping effort compared to other species in this study.

Longevity records were calculated for 341 (51\%) southern African Passeriformes species. A maximum longevity of $>5$ years was recorded for 200 of these species, with 68 of these being $>10$ years (Appendix 1). The maximum longevity record belongs to the Ploceidae, the Thick-billed Weaver (Amblyospiza albifrons), with a record of 21 years 5 months and 23 days (7847 days) (Table 1, Appendix 1, Oschadleus 2018). When grouping records by family, there was a significant correlation between the number of initial and subsequent records collected, and the maximum age recorded. The greatest species longevities of each family positively correlated to both the initial $\left(R^{2}=0.52\right)$ and subsequent $\left(R^{2}=0.52\right)$ record numbers (Figure $\left.4 \mathrm{a}, 4 \mathrm{~b}\right)$. The average reporting rate for the Passeriformes families was $9.3 \% \pm 5.4 \%$. When comparing the longevities calculated in this study to published species survival values (Table 2), a weak correlation was found $\left(R^{2}=0.12, p<0.001\right)$. Of the initial records with a known age, $92.13 \%$ were adults $(n=$ 1439 689), 7.87\% were chicks and juveniles ( $n=122$ 926) and 124056 were listed as of unknown age. Most recovery records were received from the general public (72.1\%). Causes of death were not reported for $43.8 \%$ of the recoveries, but for those with known causes, the following were most common: killed or attacked by domestic pet $(18.4 \%)$, sick or injured $(11.5 \%)$, collisions with windows and buildings $(14.3 \%)$, shot $(10.3 \%)$ and poisoned $(10.4 \%)$. Most resightings were handled by qualified ringers (> 98\%) with the remainder being sighted in the field (either metal or colour-ringed).

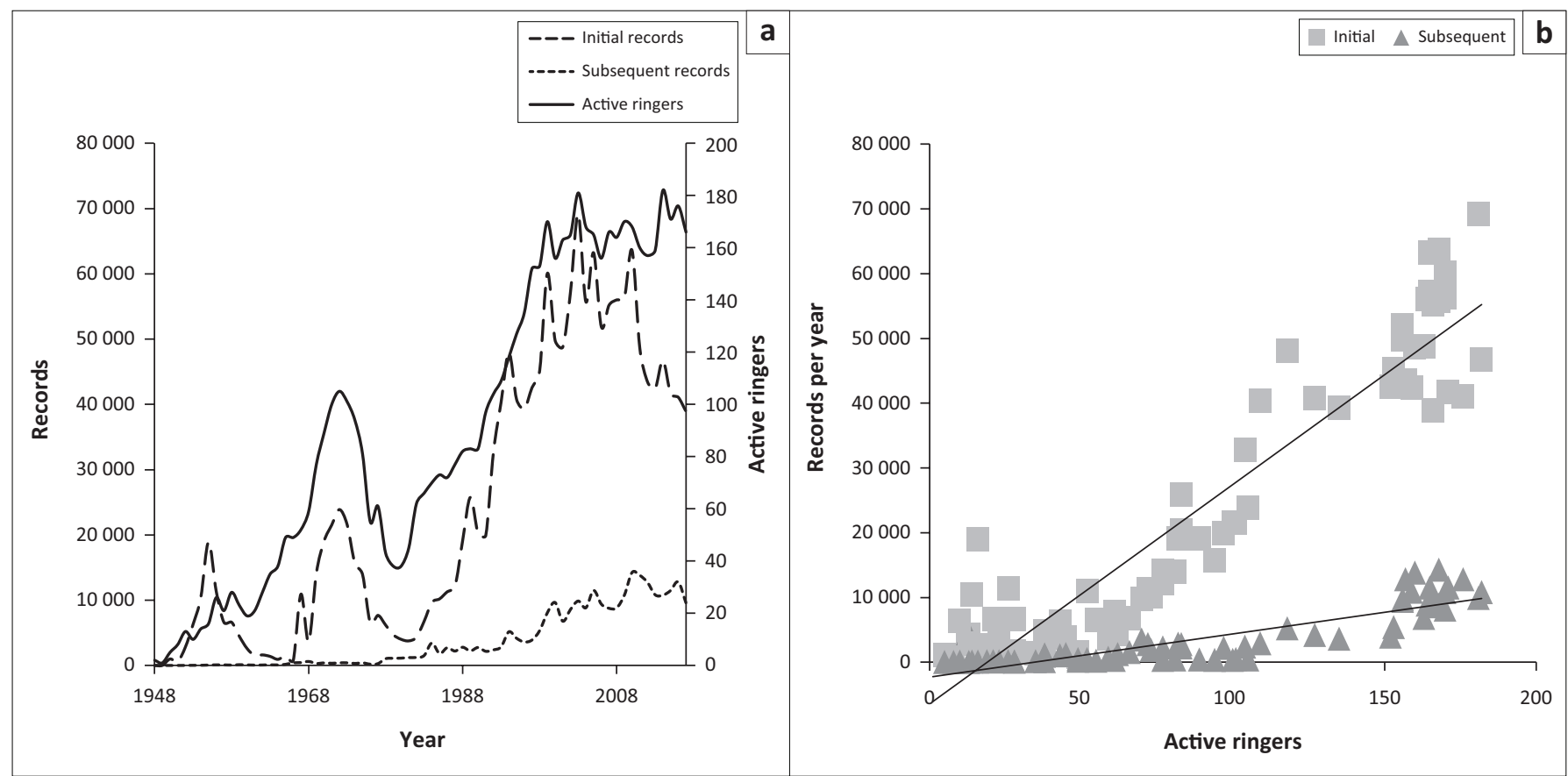

FIGURE 2: (a) Number of active ringers and Passeriformes records per year and (b) the number of active ringers compared to initial and subsequent records per year. 


\section{Discussion}

Citizen scientists have made a large and valuable contribution to the collection and collation of mass bird ringing data for Passeriformes in southern Africa. Using the current SAFRING data set, it was possible to calculate longevity values for $51 \%$ of southern African Passeriformes. The remaining 49\% of species either had no ringing records or no resightings. Accurate quantifying of survival, maximum longevity and movement measures rely on mass data collection as large numbers of subsequent sightings are needed. This study found that large numbers of initial records are needed to get the most retraps (an average of 34 retraps were produced for every 1000 birds ringed) and recoveries (an average of 4.3 recoveries were produced for every 1000 birds ringed) to calculate these values. Citizen scientists can contribute the bulk of these data throughout a species range at little to no cost for research institutions, and the more citizen scientists actively contributing data, the more reliable the longevity estimates. In addition, non-ringing citizen scientists were essential as the bulk of the recoveries were submitted by them.

Reporting rates were relatively low for Passeriformes, despite their apparent abundance in urban areas and ease of trapping. Predation of smaller birds may result in low reporting rates as the bodies may be consumed before being sighted. For some species, this is because they are short lived or seasonal, resulting in a low probability of recapture. Studies requiring greater search effort and more laborious trapping are usually undertaken by professional researchers at specific sites but will make use of citizen ringers for help (i.e. Sociable Weaver
Project, Barn Swallow Project and Red-billed Quelea Project [Underhill, Oatley \& Berruti 1995]). This coordinated effort is a likely cause for the irregular initial records to retrap count ratios seen in Figure 3, as these sites will either have constant ringing effort producing many retraps compared to initial records (as seen with the Sociable Weavers) or concentrated ringing effort producing limited retraps compared to initial records (as seen with the migrant Barn Swallow and Redbilled Quelea).

Citizen scientists involved in bird ringing are unique as they must undergo rigorous training to qualify to trap the birds, ensuring that the data collecting procedures are standardised within a scheme (De Beer et al. 2001). When in-hand, individual bird health, age, moult and measurements can be recorded (De Beer et al. 2001). The data accumulated by bird ringing can set 'benchmark' numbers for populations of common urban and/or garden species, which can be useful when detecting population change. Data highlighting this change would be most notable within highly populated areas, as ringing effort has been most consistent in these regions (Figure 1). Citizen ringing effort is usually sustained longer than most research projects, providing continuous, long-term data sets. This is especially important for threatened or invasive species where more detailed population-level analyses are required.

Two studies have analysed survival rates of southern African birds with the use of ring recovery records (Collingham et al. 2014; Peach, Hanmer \& Oatley 2001). A total of 54 species survival rates were calculated with four of these being listed in both studies (Table 2). For the Sombre Greenbul

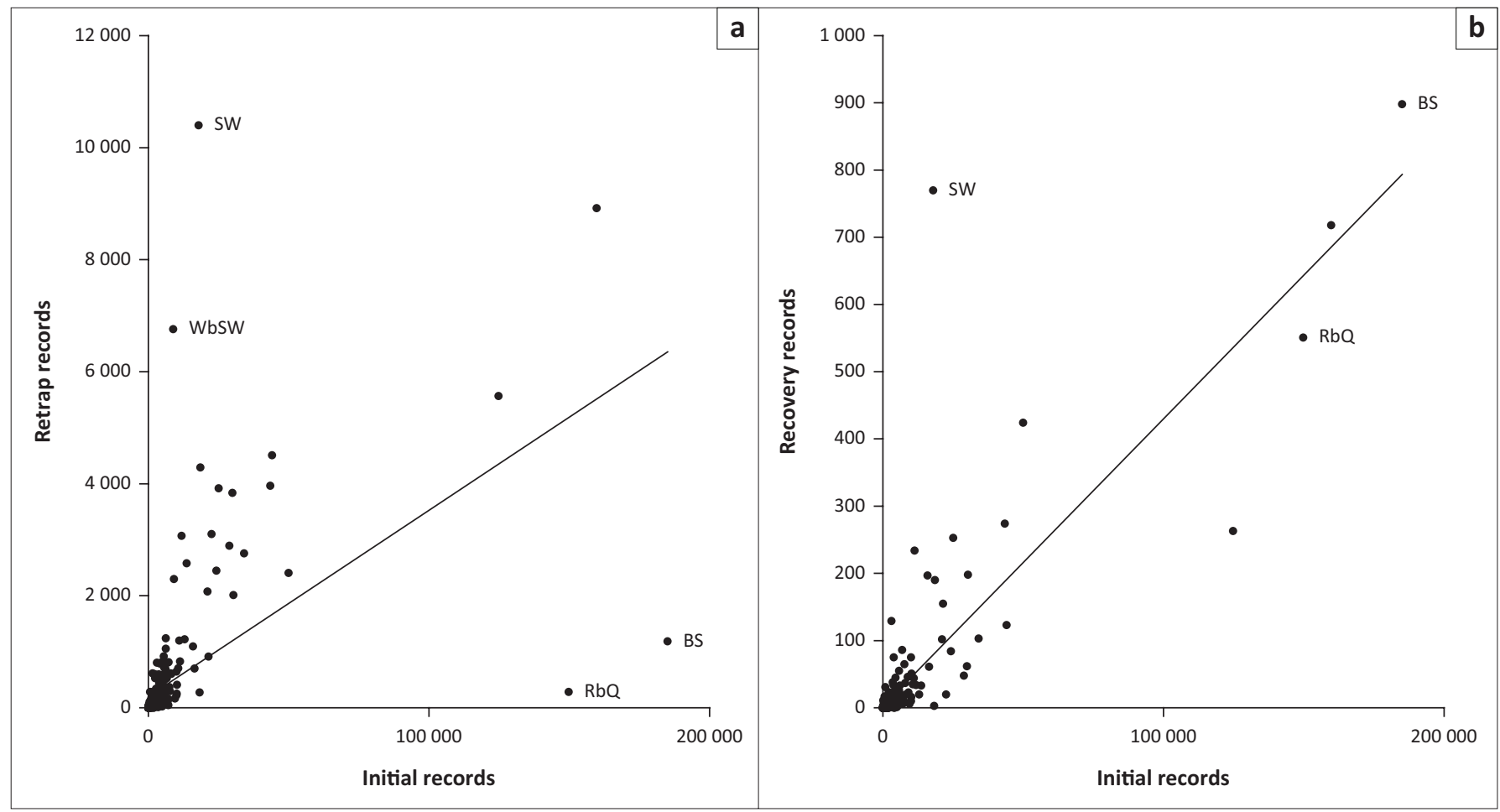

FIGURE 3: (a) Number of initial ringing records compared to retrap and (b) recovery records of each Passeriforme species (linear trend line displayed). Outlier points are SW, Sociable Weaver, WbSW, White-browed Sparrow-Weaver, RbQ, Red-billed Quelea, BS, Barn Swallow. 
TABLE 2: Published annual survival estimates (as \%) compared to longevity records from this study.

\begin{tabular}{|c|c|c|c|}
\hline Species & Survival & Source & Longevity \\
\hline Thick-billed Weaver (Amblyospiza albifrons) & 63.6 & 2 & $21 y 5 m 23 d$ \\
\hline Red-winged Starling (Onychognathus morio) & 70.5 & 2 & $18 \mathrm{y} 11 \mathrm{~m} 26 \mathrm{c}$ \\
\hline Cape Robin-Chat (Cossypha caffra) & 71.7 & 2 & $17 y 5 m 12 d$ \\
\hline Olive Thrush (Turdus olivaceus) & 64.9 & 2 & $16 y 0 m 28 d$ \\
\hline Southern Masked-Weaver (Ploceus velatus) & 62.8 & 2 & $15 y 4 m 9 d$ \\
\hline Southern Red Bishop (Euplectes orix) & $71.5,59.3$ & 1,2 & $15 y 2 m 5 d$ \\
\hline Cape Sugarbird (Promerops cafer) & 62.7 & 2 & $14 y 7 m 14 d$ \\
\hline Dark-capped Bulbul (Pycnonotus tricolor) & 71.1 & 2 & $14 \mathrm{y} 10 \mathrm{~m} 15 \mathrm{c}$ \\
\hline Cape Weaver (Ploceus capensis) & 65.5 & 2 & $13 y 7 m 22 d$ \\
\hline Lesser Swamp-Warbler (Acrocephalus gracilirostris) & 55.7 & 1 & $13 y 1 m 29 d$ \\
\hline Village Weaver (Ploceus cucullatus) & 66.5 & 2 & $13 y 11 \mathrm{~m} 8 d$ \\
\hline Cape Wagtail (Motacilla capensis) & 67.3 & 2 & $13 y 0 m 12 d$ \\
\hline Sombre Greenbul (Andropadus importunus) & $68.1,65.2$ & 1,2 & 12 y $9 \mathrm{~m} 12 d$ \\
\hline Common Fiscal (Lanius collaris) & 61.6 & 2 & $12 \mathrm{y} 7 \mathrm{~m} \mathrm{2d}$ \\
\hline Southern Brown-throated Weaver (Ploceus xanthopterus) & 69.6 & 1 & $12 y 5 m 16 d$ \\
\hline African Reed-warbler (Acrocephalus baeticatus) & 76.5 & 1 & $12 \mathrm{y} 2 \mathrm{~m} 15 \mathrm{~d}$ \\
\hline African Red-eyed Bulbul (Pycnonotus nigricans) & 62.6 & 2 & $12 y 0 m 6 d$ \\
\hline White-browed Robin-Chat (Cossypha heuglini) & 83.3 & 1 & $11 y 9 m$ od \\
\hline Brimstone Canary (Serinus sulphuratus) & 52.2 & 1 & $11 y 7 m$ 13d \\
\hline Fiscal Flycatcher (Sigelus silens) & 63.1 & 2 & $11 y 5 m 1 d$ \\
\hline Cape Bulbul (Pycnonotus capensis) & 62.8 & 2 & $11 y 4 m 5 d$ \\
\hline White-browed Sparrow-Weaver (Plocepasser mahali) & 55.6 & 2 & $11 y 3 m 18 d$ \\
\hline Yellow Bishop (Euplectes capensis) & 54.0 & 1 & $11 y 0 m 27 d$ \\
\hline Terrestrial Brownbul (Phyllastrephus terrestris) & 73.7 & 1 & $10 y 8 m 14 d$ \\
\hline Yellow-fronted Canary (Serinus mozambicus) & 64.8 & 1 & $10 y 5 m 17 d$ \\
\hline Yellow-breasted Apalis (Apalis flavida) & 68.0 & 1 & $10 y 4 m 20 d$ \\
\hline Cape Sparrow (Passer melanurus) & 57.8 & 2 & $10 y 11 \mathrm{~m} 4 \mathrm{~d}$ \\
\hline Collared Sunbird (Anthreptes collaris) & 75.7 & 1 & $10 y 0 m 8 d$ \\
\hline Malachite Sunbird (Nectarinia famosa) & 62.7 & 2 & $10 y 0 m 14 d$ \\
\hline Southern Grey-headed Sparrow (Passer diffusus) & 50.3 & 2 & 9y $3 \mathrm{~m} \mathrm{Od}$ \\
\hline Wire-tailed Swallow (Hirundo smithii) & 63.5 & 1 & $9 y 2 m 7 d$ \\
\hline Scarlet-chested Sunbird (Nectarinia senegalensis) & 90.3 & 1 & $9 y 2 m 11 d$ \\
\hline Bleating Warbler (Camaroptera brachyura) & 73.5 & 1 & $9 y 1 m 24 d$ \\
\hline Mountain Wagtail (Motacilla clara) & 75.3 & 2 & $9 y 1 \mathrm{~m} 18 \mathrm{~d}$ \\
\hline Common Waxbill (Estrilda astrild) & $61.2,40.8$ & 1,2 & $8 y 8 m 0 d$ \\
\hline Green-backed Camaroptera (Camaroptera brachyura) & 73.5 & 1 & $8 y 7 m 10 d$ \\
\hline Variable Sunbird (Nectarinia venusta) & 54.9 & 1 & $8 y 3 m 25 d$ \\
\hline South African Cliff-Swallow (Hirundo spilodera) & 38.2 & 2 & $8 y 3 m 11 d$ \\
\hline Red-headed Finch (Amadina erythrocephala) & 42.0 & 2 & $8 y 2 m 17 d$ \\
\hline Great Reed-Warbler (Acrocephalus arundinaceus) & 59.0 & 1 & $8 y 1 \mathrm{~m} 11 \mathrm{~d}$ \\
\hline Long-billed Crombec (Sylvietta rufescens) & 79.5 & 1 & $8 y 0 m 5 d$ \\
\hline Red-faced Cisticola (Cisticola erythrops) & 52.9 & 1 & $7 y 5 m 6 d$ \\
\hline Red-billed Quelea (Quelea quelea) & 25.0 & 2 & $7 y 4 m 2 d$ \\
\hline Basra Reed-Warbler (Acrocephalus griseldis) & 63.8 & 1 & $7 y 11 \mathrm{~m} 7 \mathrm{~d}$ \\
\hline Pin-tailed Whydah (Vidua macroura) & 63.7 & 2 & $7 y 10 m 26 d$ \\
\hline Purple-banded Sunbird (Nectarinia bifasciata) & 76.1 & 1 & $7 y 10 m 24 d$ \\
\hline Green-winged Pytilia (Pytilia melba) & 51.9 & 1 & $7 y 10 m$ 10d \\
\hline Village Indigobird (Vidua chalybeata) & 54.2 & 1 & $6 y 2 m 18 d$ \\
\hline Copper Sunbird (Nectarinia cuprea) & 59.9 & 1 & $6 y 0 m 15 d$ \\
\hline Red-billed Firefinch (Lagonosticta senegala) & 22.8 & 1 & $5 y 4 m 11 d$ \\
\hline Jameson's Firefinch (Lagonosticta rhodopareia) & 49.9 & 1 & $5 y 0 m 23 d$ \\
\hline Garden Warbler (Sy/via borin) & 54.0 & 1 & $4 y 11 \mathrm{~m} 11 \mathrm{~d}$ \\
\hline
\end{tabular}

Note: Sources column data -

1, Peach, W.J., Hanmer, D.B. \& Oatley, T.B., 2001, 'Do southern African songbirds live longer than their European counterparts?', Oikos 93, 235-249. https://doi.org/10.1034/j.1600-0706.2001.930207.x 2, Collingham, Y.C., Huntley, B., Altwegg, R., Barnard, P., Beveridge, O.S., Gregory, R.D. et al., 2014, 'Prediction of mean adult survival rates of southern African birds from demographic and ecological covariates', Ibis 156(4), 741-754. https://doi.org/10.1111/ibi.12195 


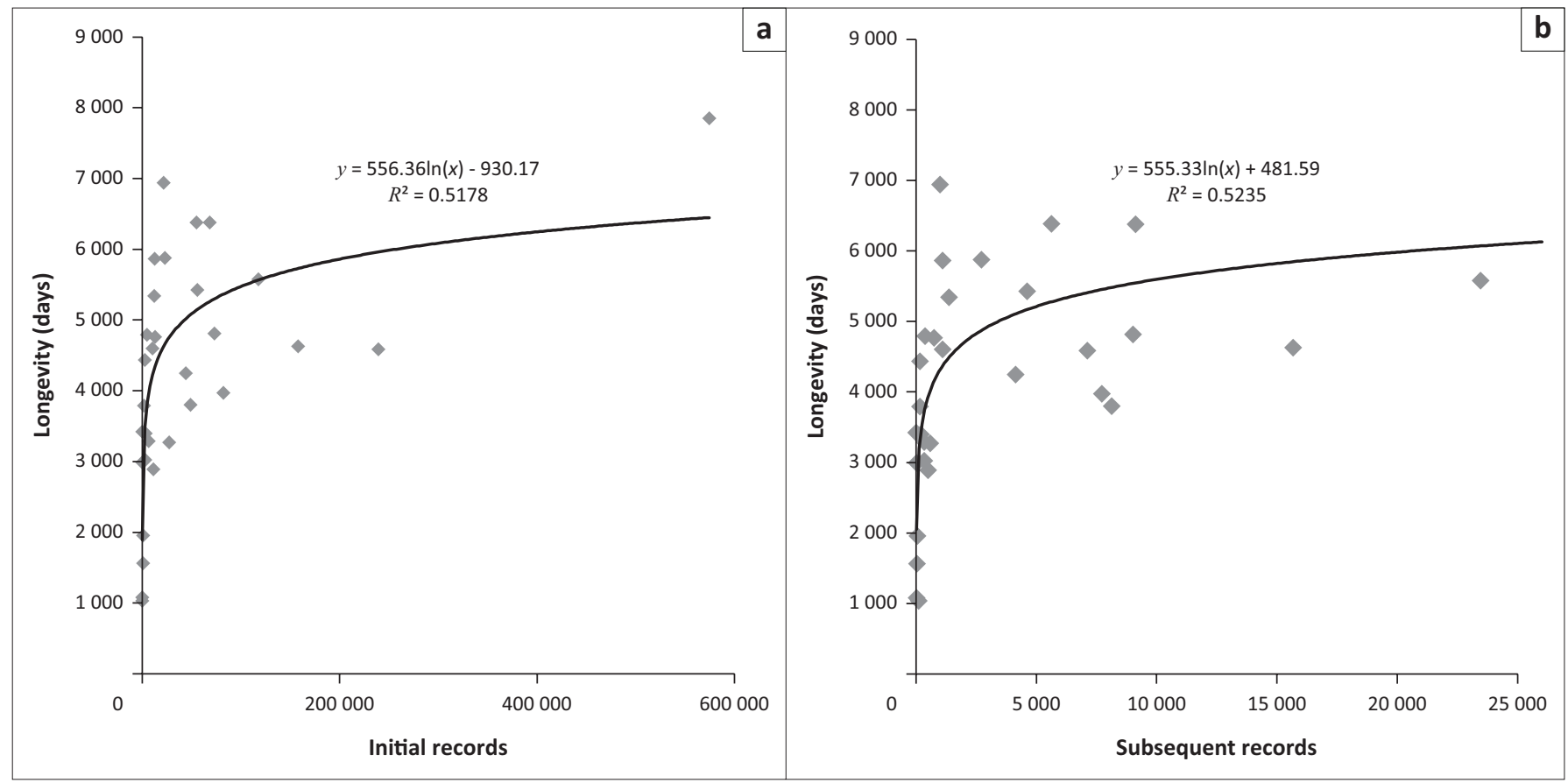

FIGURE 4: Number of (a) initial and (b) subsequent records compared to maximum longevity (days) of each Passeriformes family (logarithmic trend line displayed).

(Andropadus importunus), both studies had similar survival rates, while there were large differences $(10 \%-20 \%)$ for the other three species. This highlights the difficulties of working with estimates calculated from limited samples and emphasises the need for active ringing to take place across large temporal and spatial scales.

\section{Conclusion}

While the contribution of citizen ringers to research projects in southern Africa is clearly valuable, these results identify gaps in the ringing data and highlight many of the species requiring additional sampling effort. Table 1 identifies the Passeriformes families that are likely data deficient as most of the families were able to achieve longevities of over 10 years, while those obtaining longevity records of less than 5 years, such as the Chaetopidae, likely require a greater ringing effort. To increase the reliability of longevity estimates, coordinated ringing activities should target sites where data-deficient Passeriformes species occur.

\section{Acknowledgements}

The authors would like to thank all SAFRING ringers and the general public (the latter in reporting recoveries) that have taken part in ringing and resighting in southern Africa. They specially thank Bennie van den Brink, Ursula Franke-Bryson, Kobie Raijmakers, Gerrie Grobler and Margaret McCall whose data made up over $12 \%$ of all initial Passeriformes records processed for this article.

\section{Competing interests}

The authors declare that that they have no financial or personal relationships that may have inappropriately influenced them in writing this article.

\section{Authors' contributions}

D.M.P., S.R. and H.D.O. contributed to the design and implementation of the research, analysis of the results and writing of the manuscript.

\section{Funding}

The South African Bird Ringing Unit was sponsored by the South African National Biodiversity Institute, Vulpro and the Namibian Ministry of Wildlife and Tourism. The University of Cape Town provided accommodation and services.

\section{Data availability statement}

Data sharing is not applicable to this article as no new data were created or analysed in this study.

\section{Disclaimer}

The views and opinions expressed in this article are those of the authors and do not necessarily reflect the official policy or position of any affiliated agency of the authors.

\section{References}

Baillie, S., 2001, 'The contribution of ringing to the conservation and management of bird populations: A review', Ardea 89(1), 167-184.

BirdLife International, 2017, The IUCN red list of threatened species 2017, viewed 24 March 2018, from http://www.iucnredlist.org/

Collingham, Y.C., Huntley, B., Altwegg, R., Barnard, P., Beveridge, O.S., Gregory, R.D. et al., 2014, 'Prediction of mean adult survival rates of southern African birds from demographic and ecological covariates', Ibis 156(4), 741-754. https://doi. org/10.1111/ibi.12195

De Beer, S.J., Lockwood, G.M., Raijmakers, J.H.F.A., Raijmakers, J.M.H., Scott, W.A., Oschadleus, H.D. et al., 2001, SAFRING bird ringing manual, 2nd edn., Animal Demography Unit, Cape Town.

Elliott, C.C.H., 1971, 'Bird ringing in Southern Africa', in K. Newman (ed.), Birdlife in southern Africa, pp. 217-226, Purnell \& sons, Johannesburg.

Gill, F. \& Donsker, D. (eds.), 2016, IOC world bird list (v 6.2), viewed n.d., from http:// www.worldbirdnames.org 
Haklay, M., 2013, Citizen science and volunteered geographic information Overview and typology of participation, in A. Ballatore, M. Bertolotto \& D.C.
Wilson (eds.), Crowdsourcing geographic knowledge, pp. 105-122, Springer, Wilson (eds.
Netherlands.

Lever, C., 2010, Naturalised birds of the world, T \& D Poyser Monographs, London.

Oschadleus, H.D., 2018, 'Thick-billed Weaver longevity', Hornbill 128, 32.

Paijmans, D.M., Catto, S. \& Oschadleus, H.D., 2017, 'SAFRING ringing report for 2016', Biodiversity Observations 8(36), 1-8.

Peach, W.J., Hanmer, D.B. \& Oatley, T.B., 2001, 'Do southern African songbirds live longer than their European counterparts?', Oikos 93, 235-249. https://doi. org/10.1034/j.1600-0706.2001.930207.x
Rising, J. \& Bonan, A., 2017, 'Old world buntings (Emberizidae)', in J. del Hoyo, A. Elliott, J. Sargatal, D. Christie \& E. de Juana (eds.), Handbook of the birds of the world alive, viewed 25 March 2018, from https://www.hbw.com

Robinson, R.A., Julliard, R. \& Saracco, J.F., 2009, 'Constant effort: Studying avian population processes using standardised ringing', Ringing \& Migration 24(3), 199-204. https://doi.org/10.1080/03078698.2009.9674392

Underhill, L.G., Oatley, T.B., Berruti, A., 1995, Bird ringing in southern Africa. Projects for the future, ADU Guide 2, Avian Demography Unit, Cape Town.

Wasser, D.E. \& Sherman, P.W., 2010, 'Avian longevities and their interpretation under evolutionary theories of senescence', Journal of Zoology 280, 103-155. https:// doi.org/10.1111/j.1469-7998.2009.00671.x 


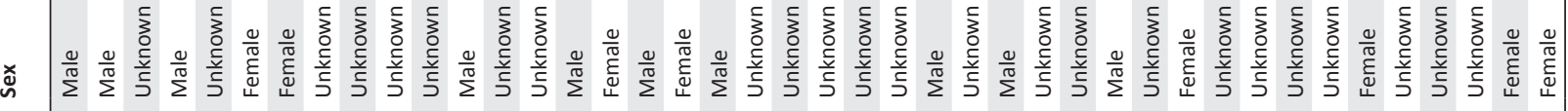

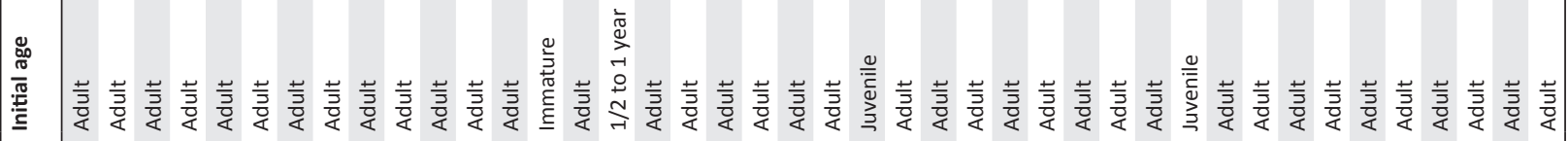

능요

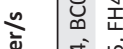

等 至

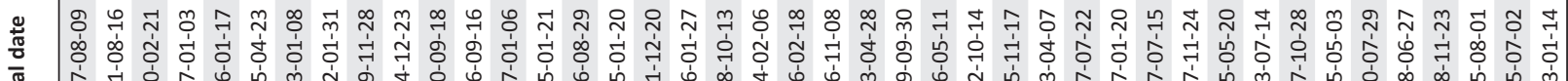

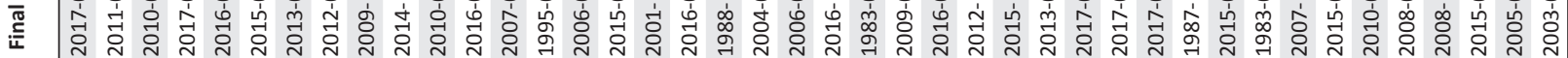

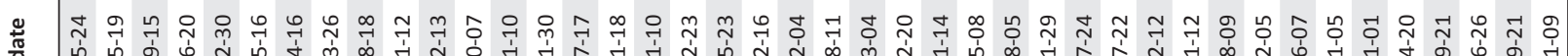
范 胥

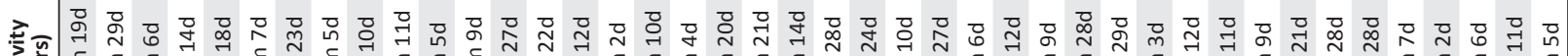

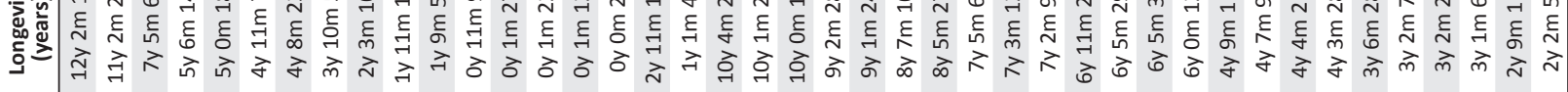

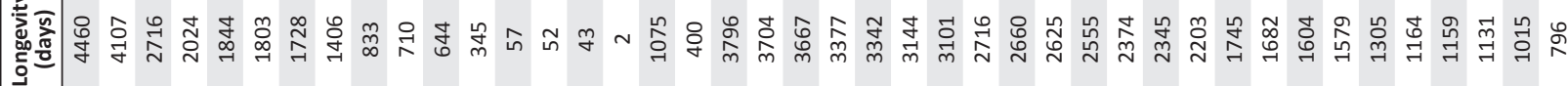

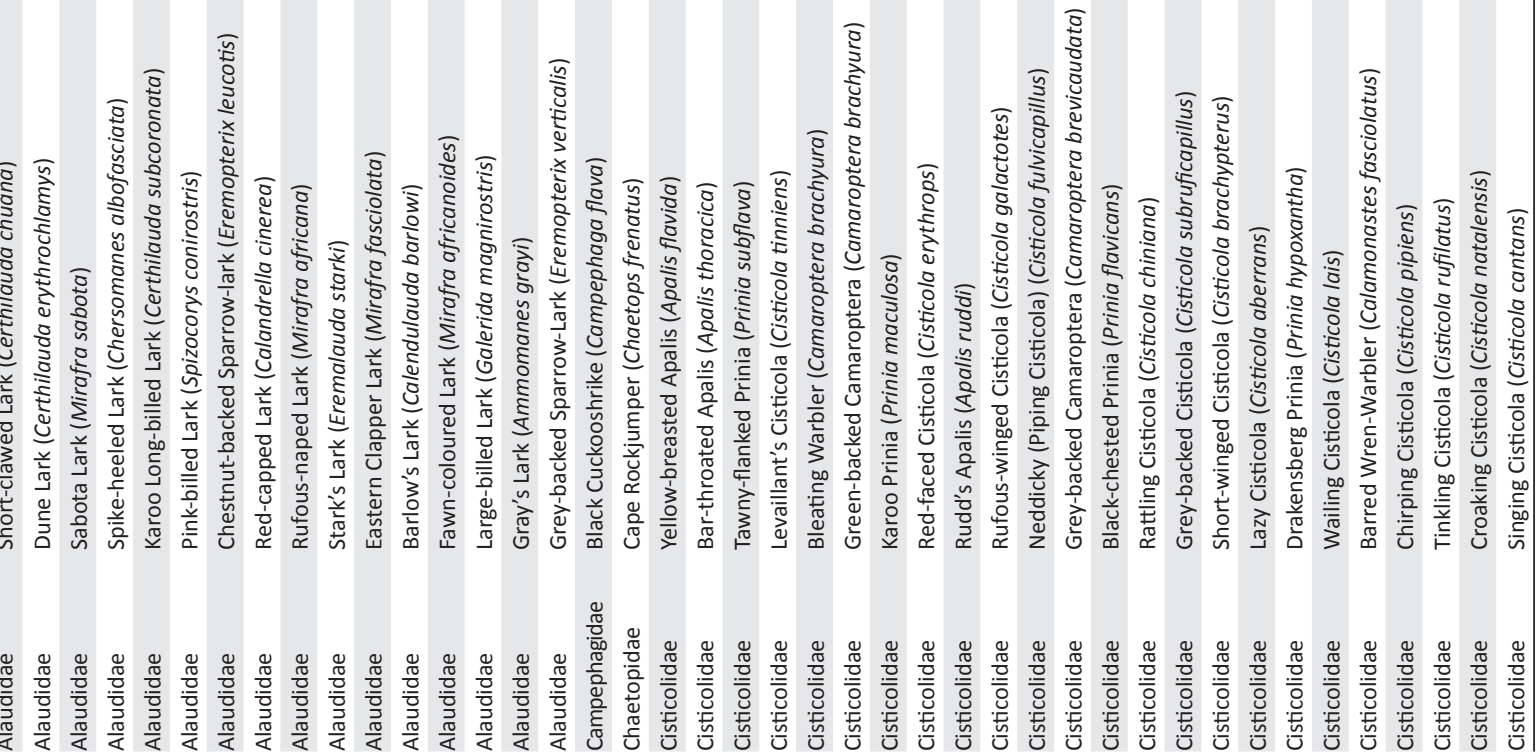




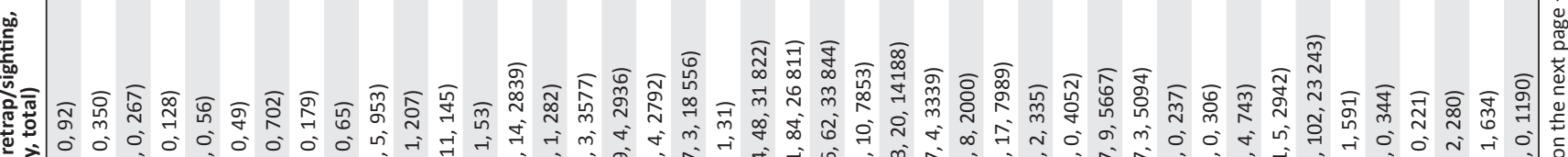

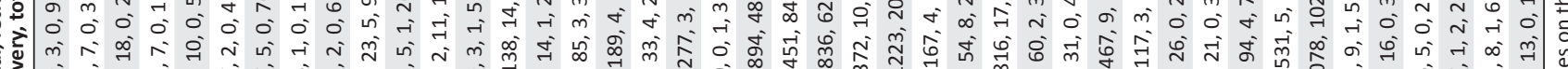

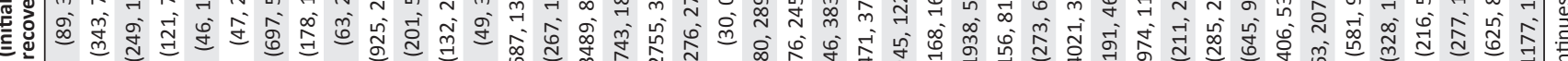

苞

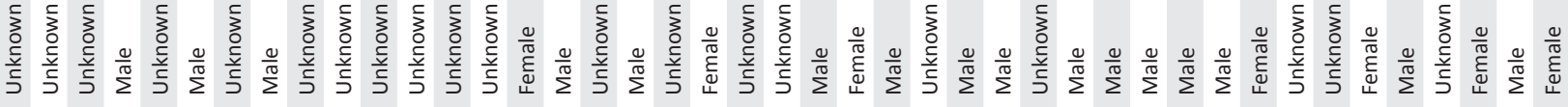

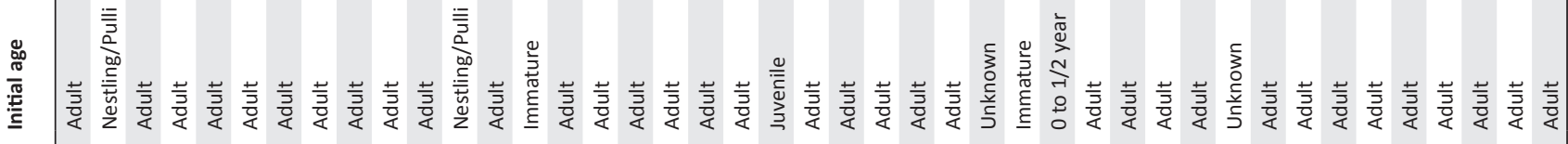

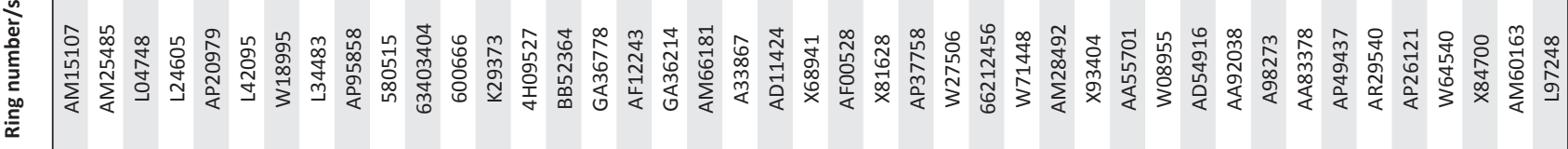

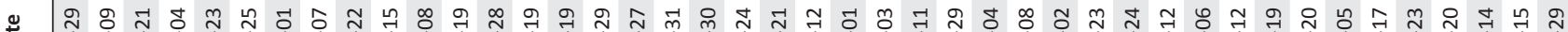
范

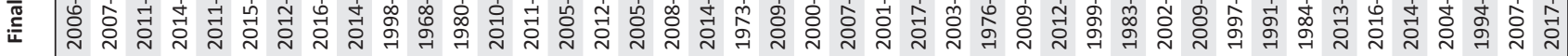

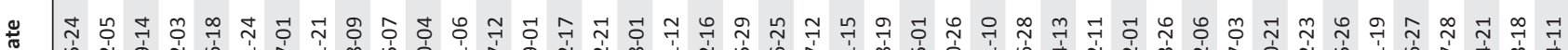
-

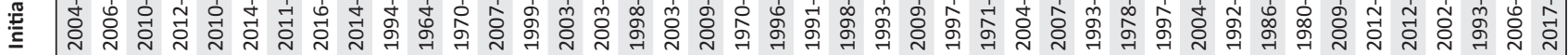

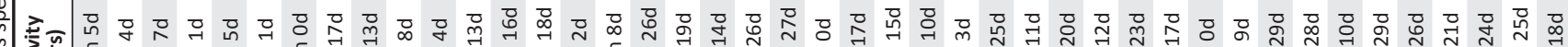

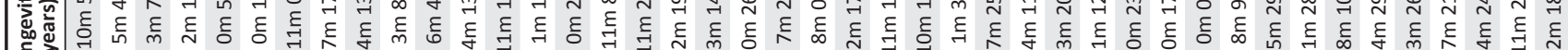

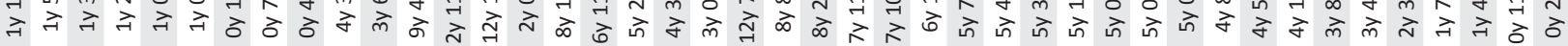

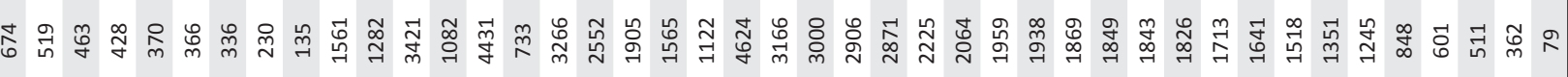

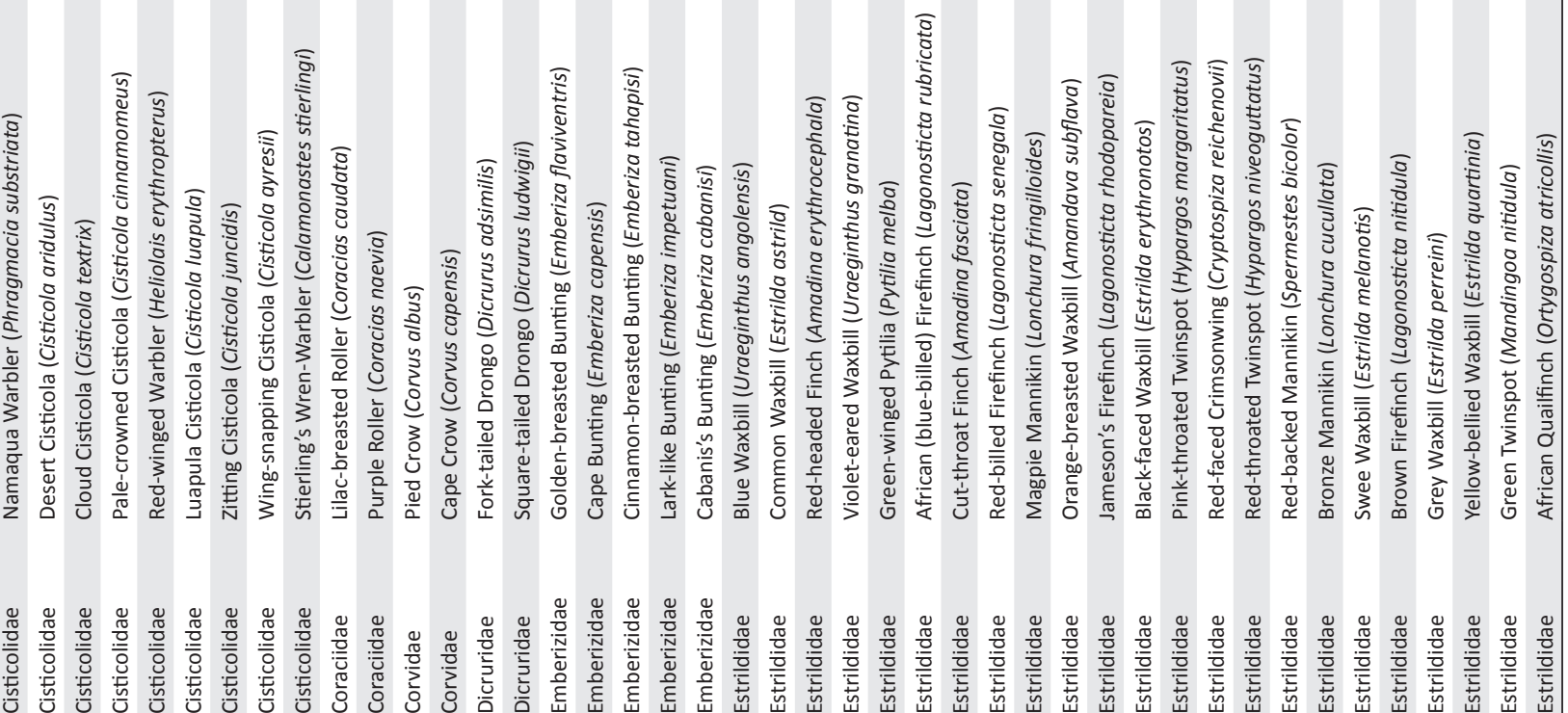




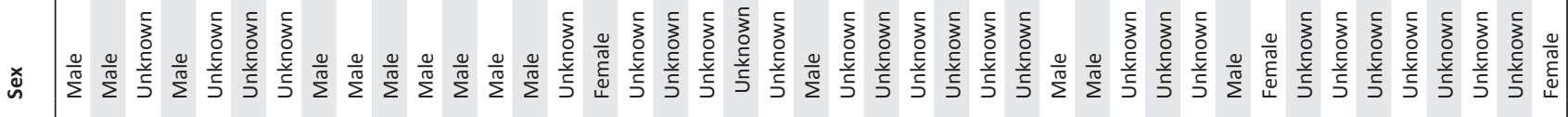

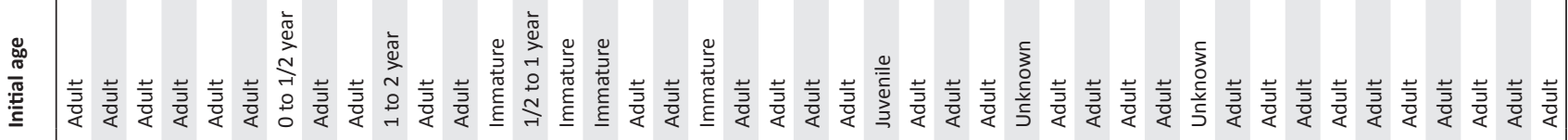

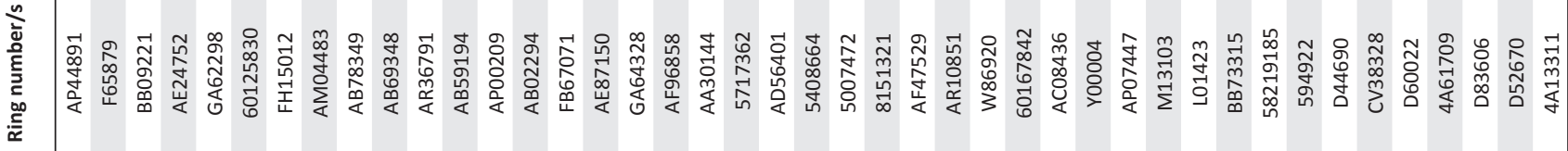

은

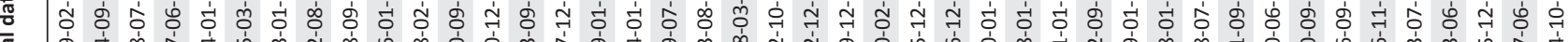

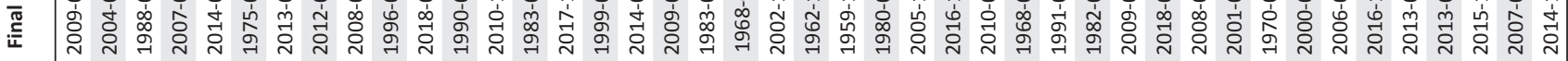

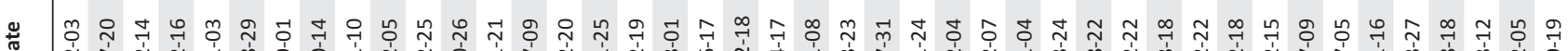

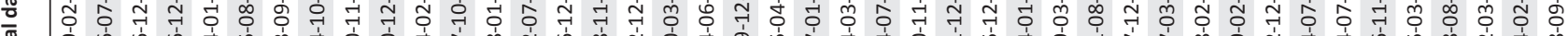
昰

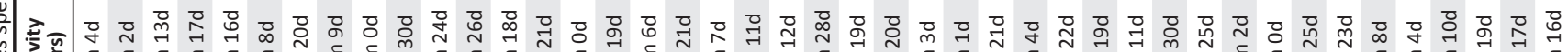

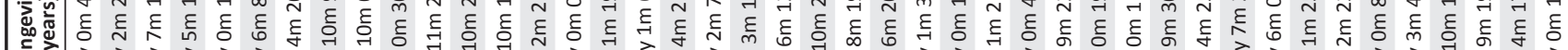

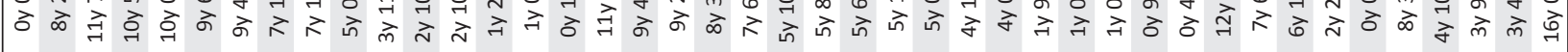

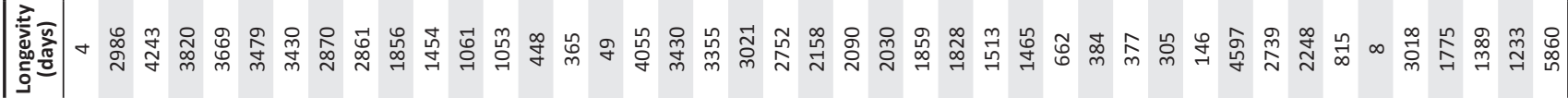

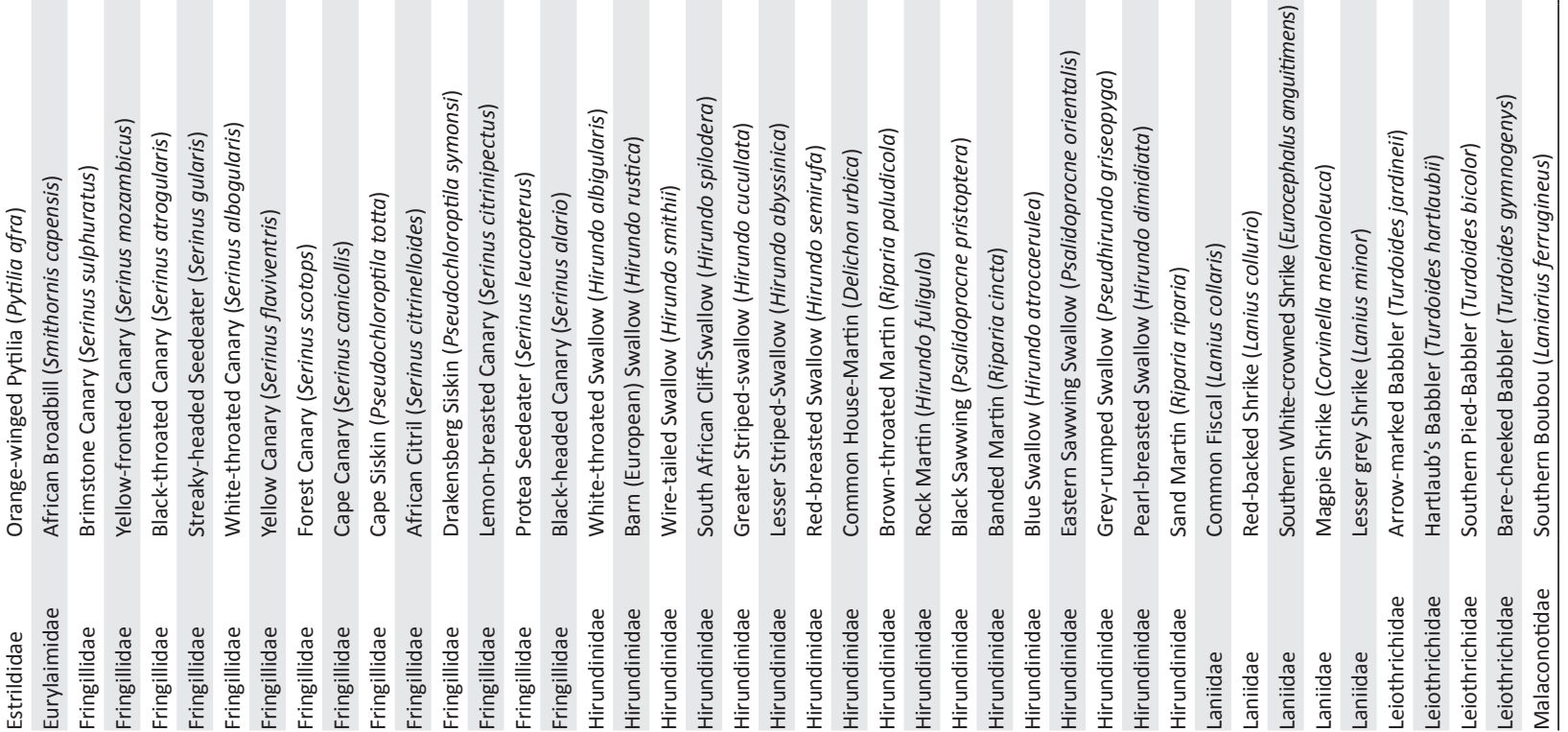




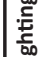

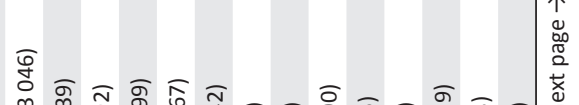

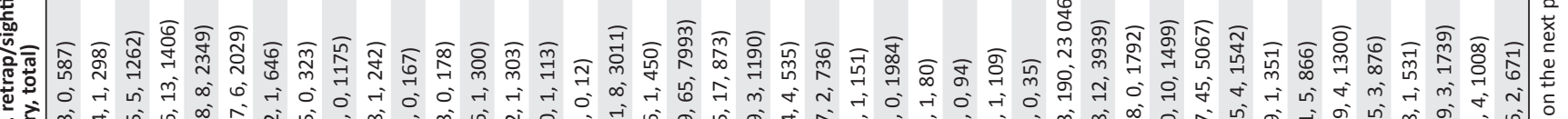

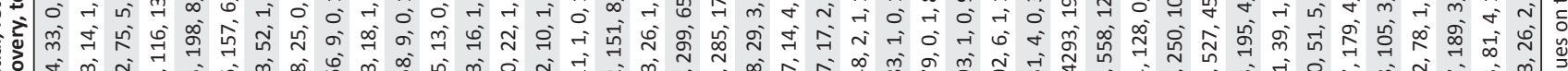

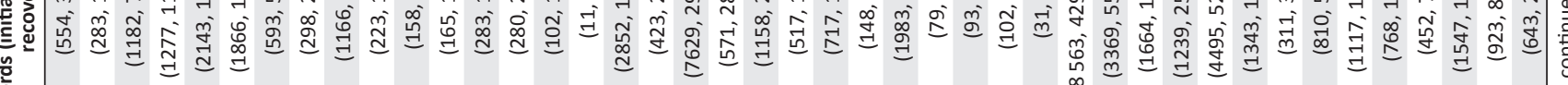

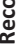

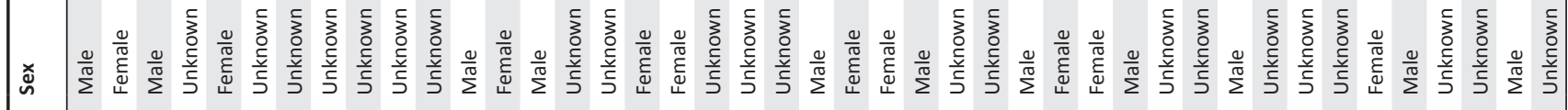

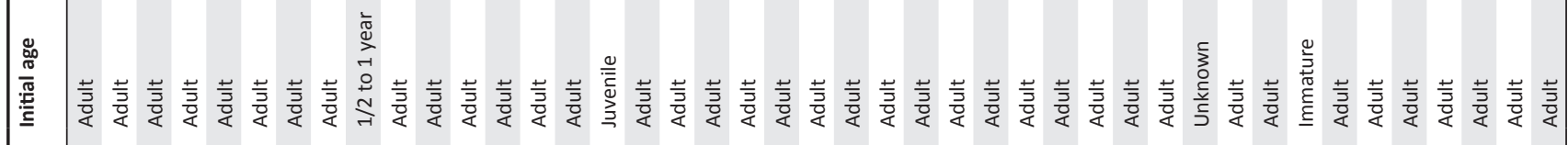

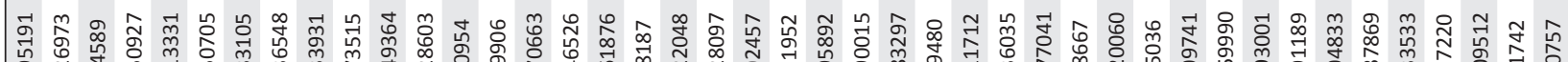

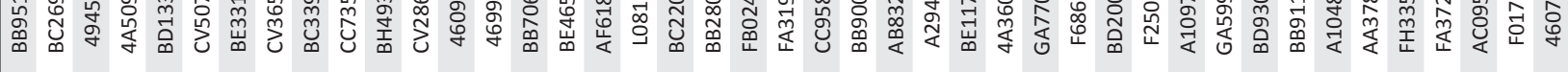

\& ఇ

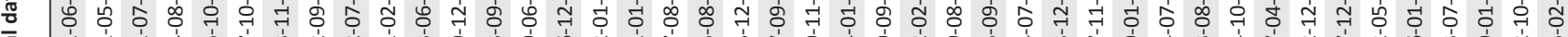

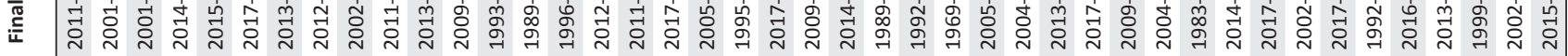

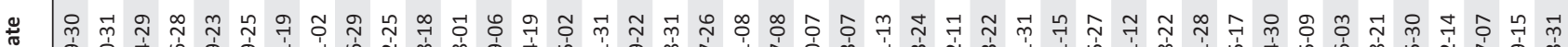

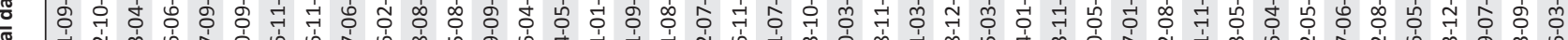

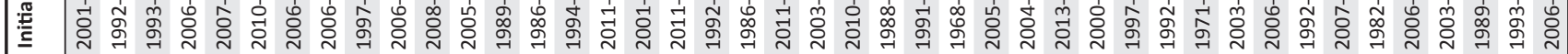

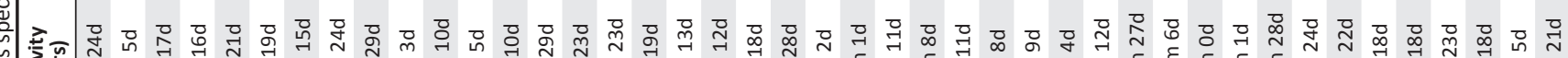
屯ै

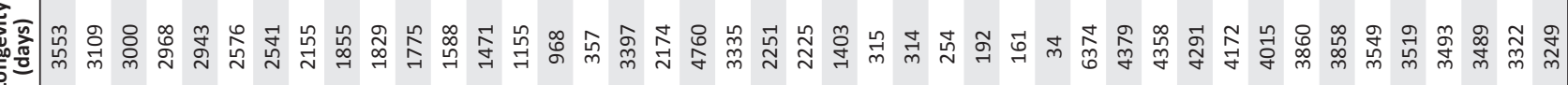

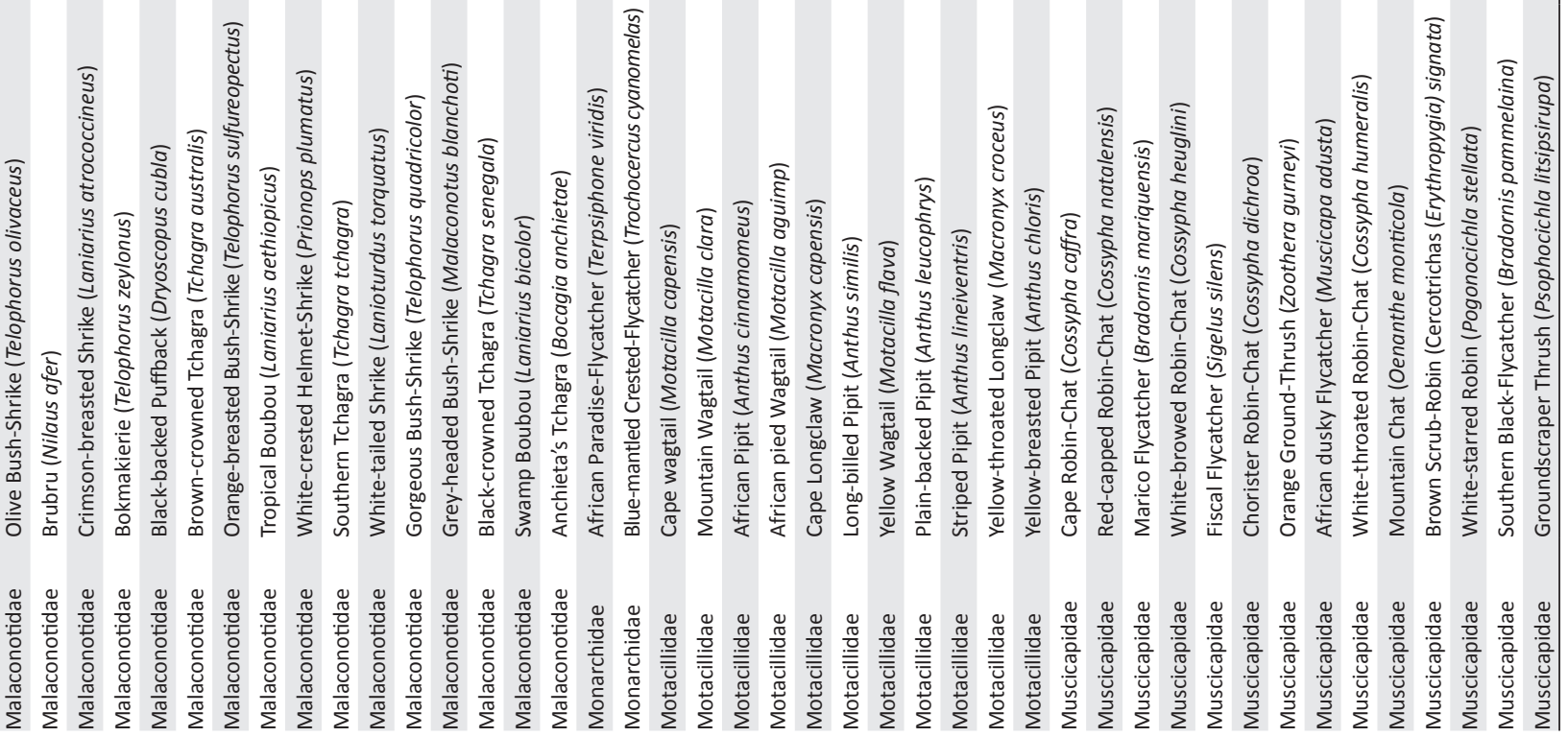




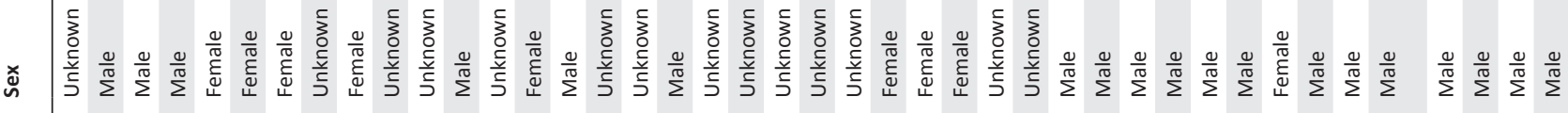

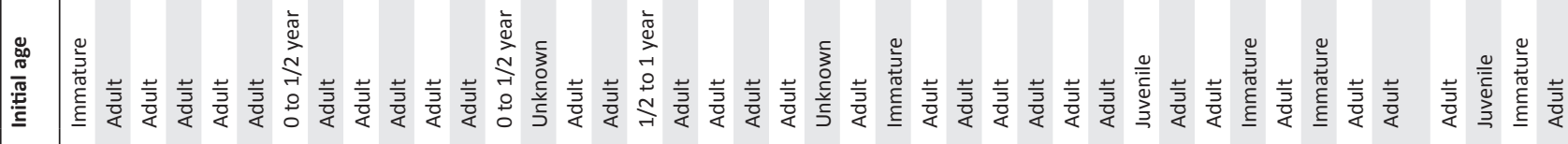

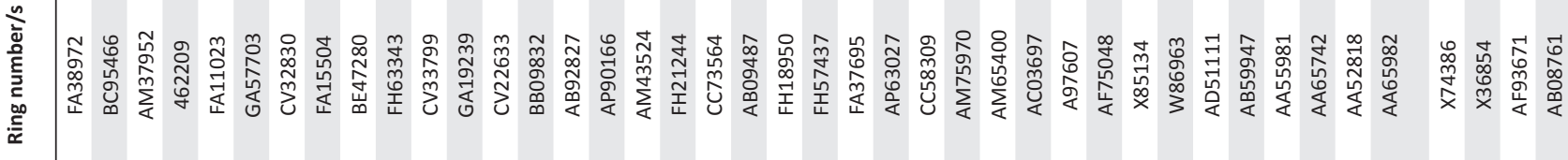

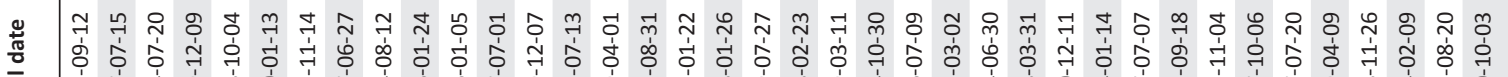
ก

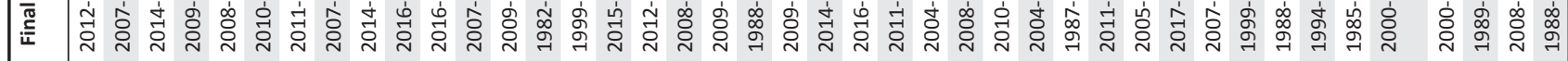
苟 "

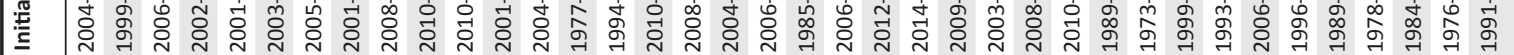

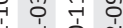

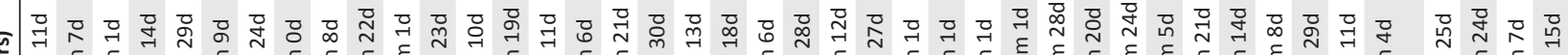

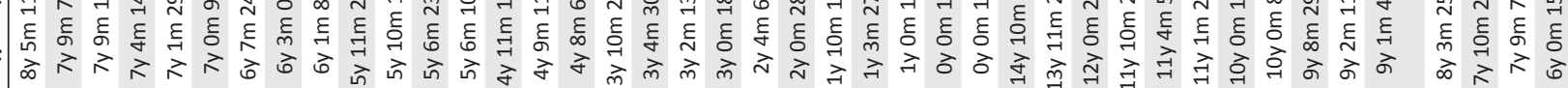

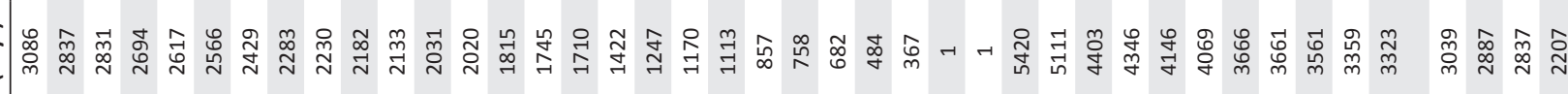

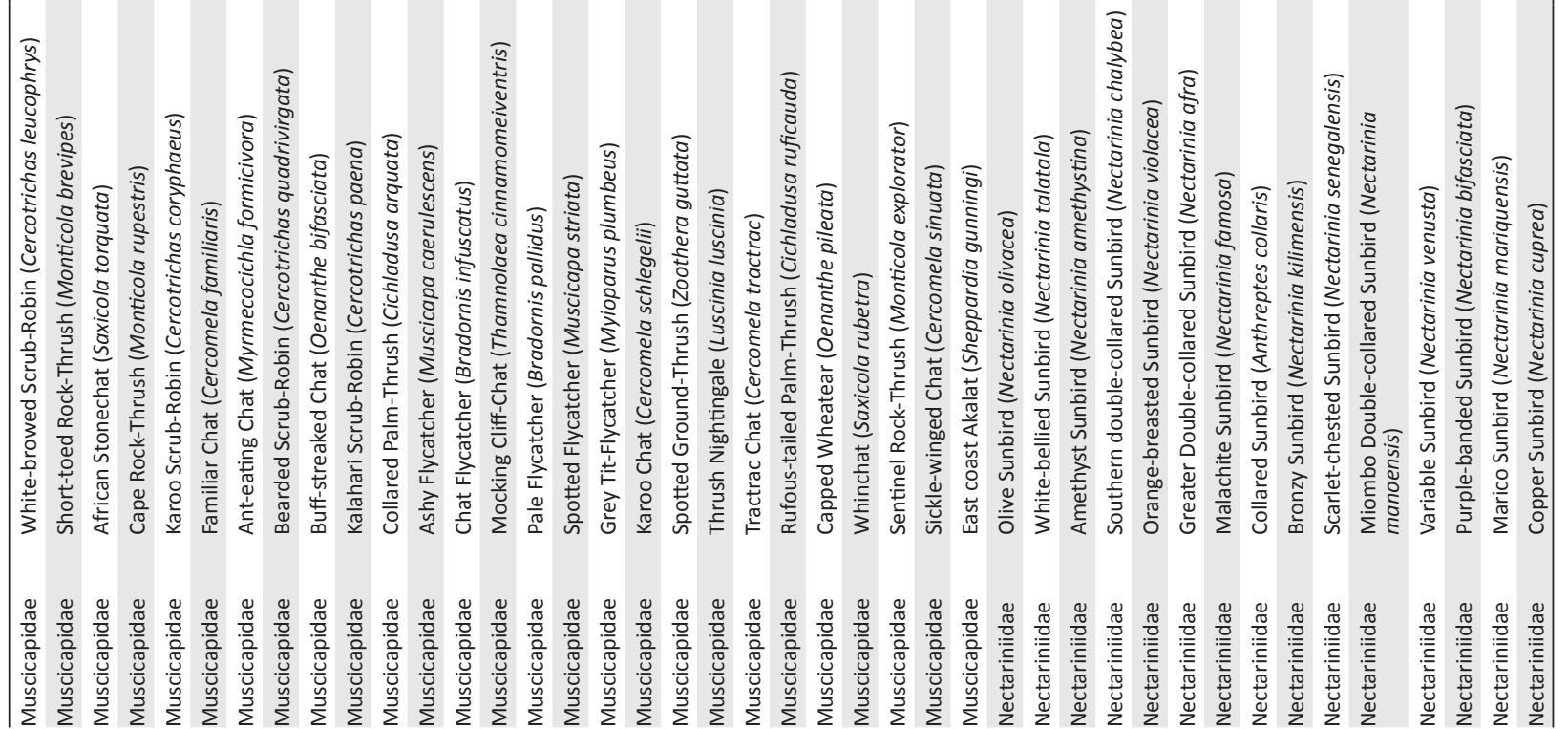




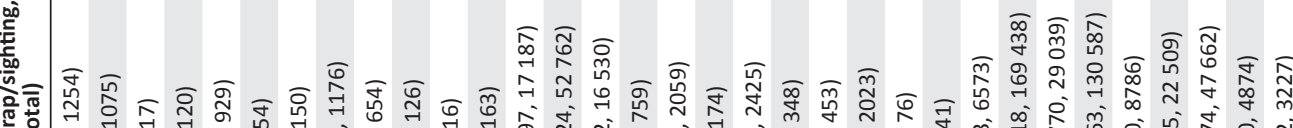

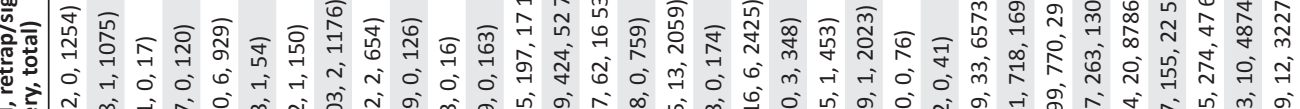

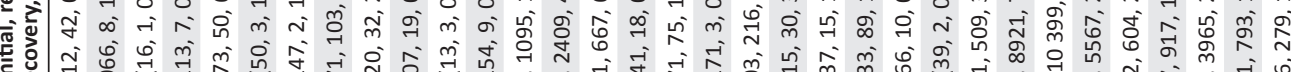

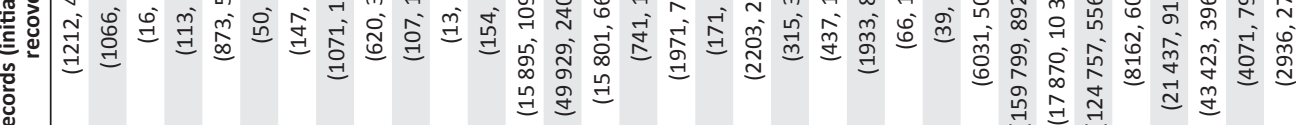

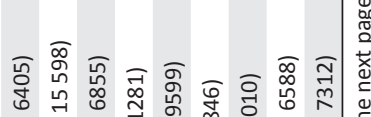
तो की 嵌

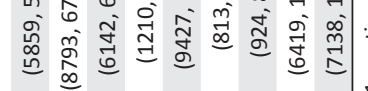

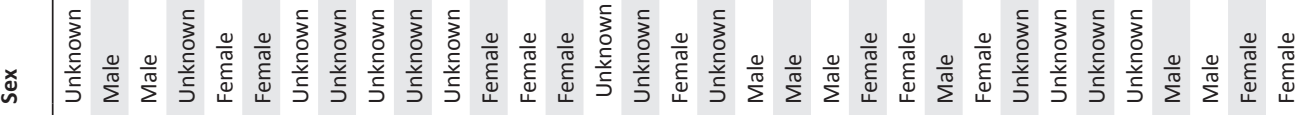

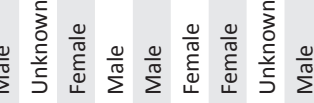

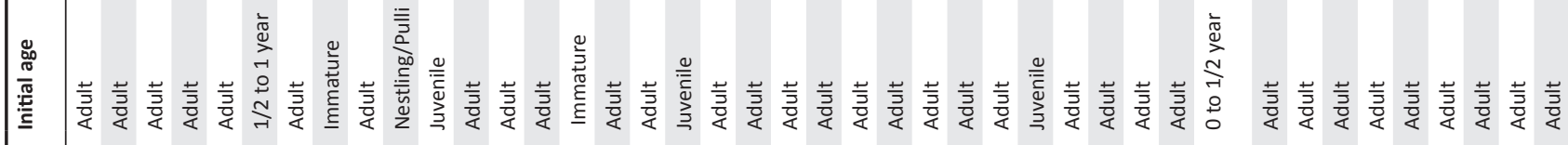

沛 ๙

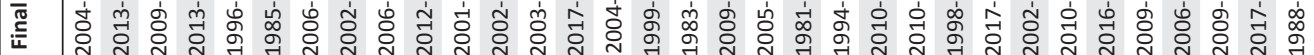

둥

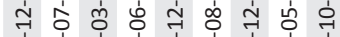
‡ 온

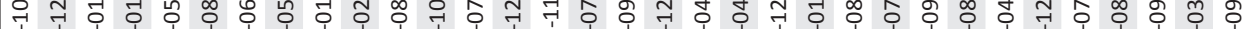
焉

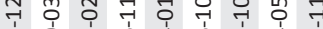

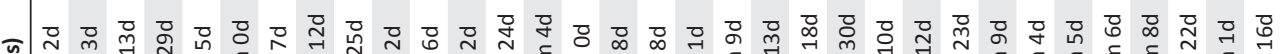

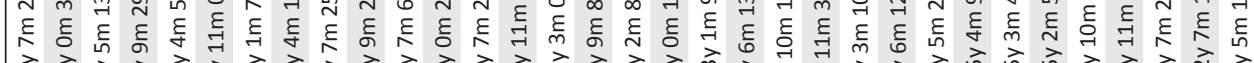

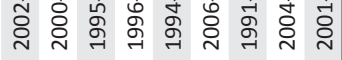

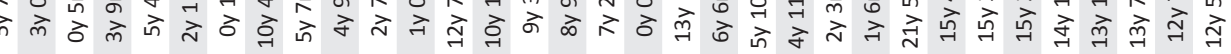

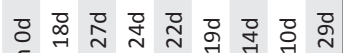

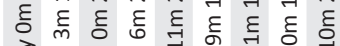

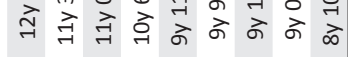

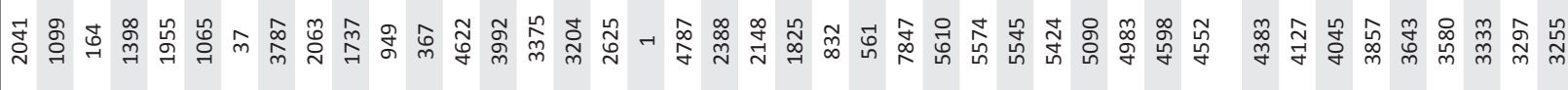

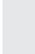

$\sqrt{\frac{2}{2}}$

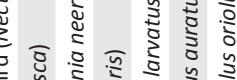

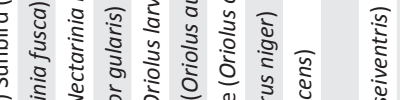

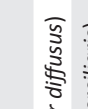

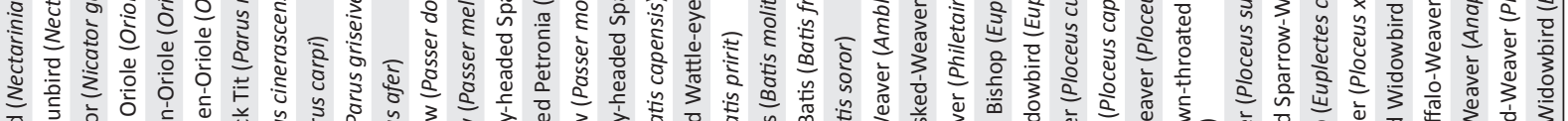

$\frac{2}{2}$ $\begin{array}{llll} & \\ 0\end{array}$

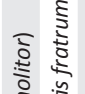

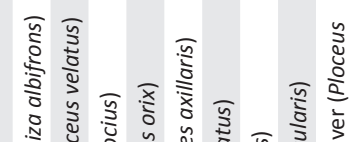

)

衰 产

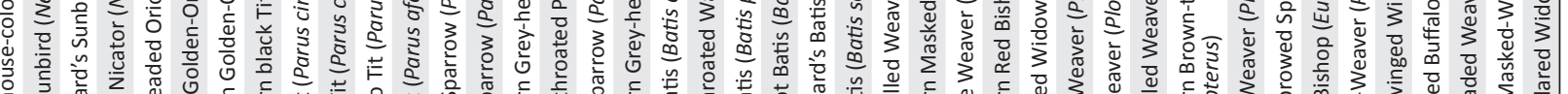
$\begin{array}{llll} & \\ 0\end{array}$ 


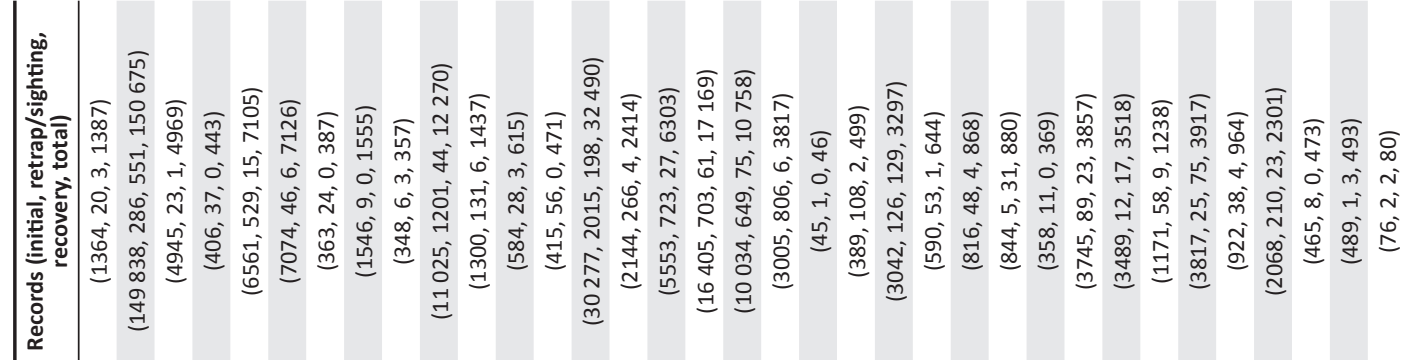

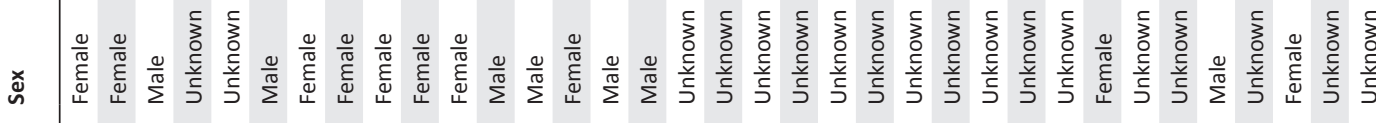

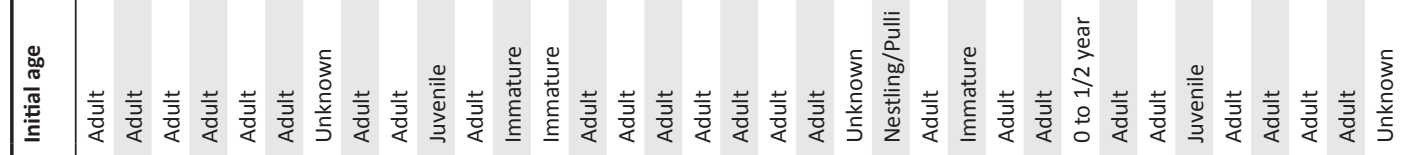

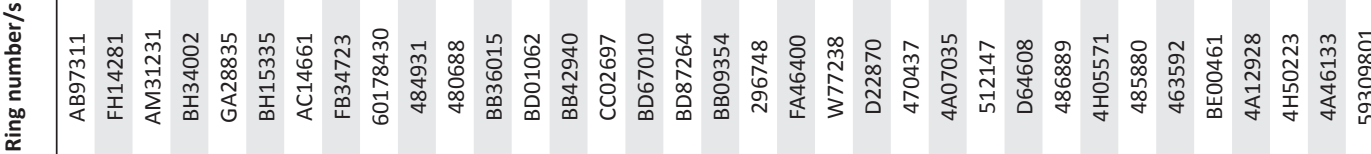

ะ ரٓ 疍 䒕 \%

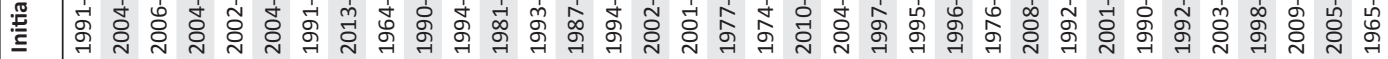

\沉

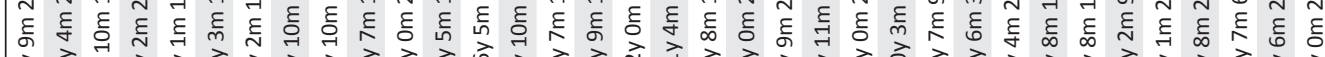

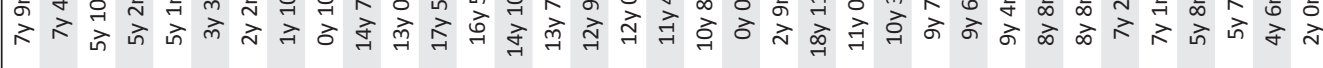
梁

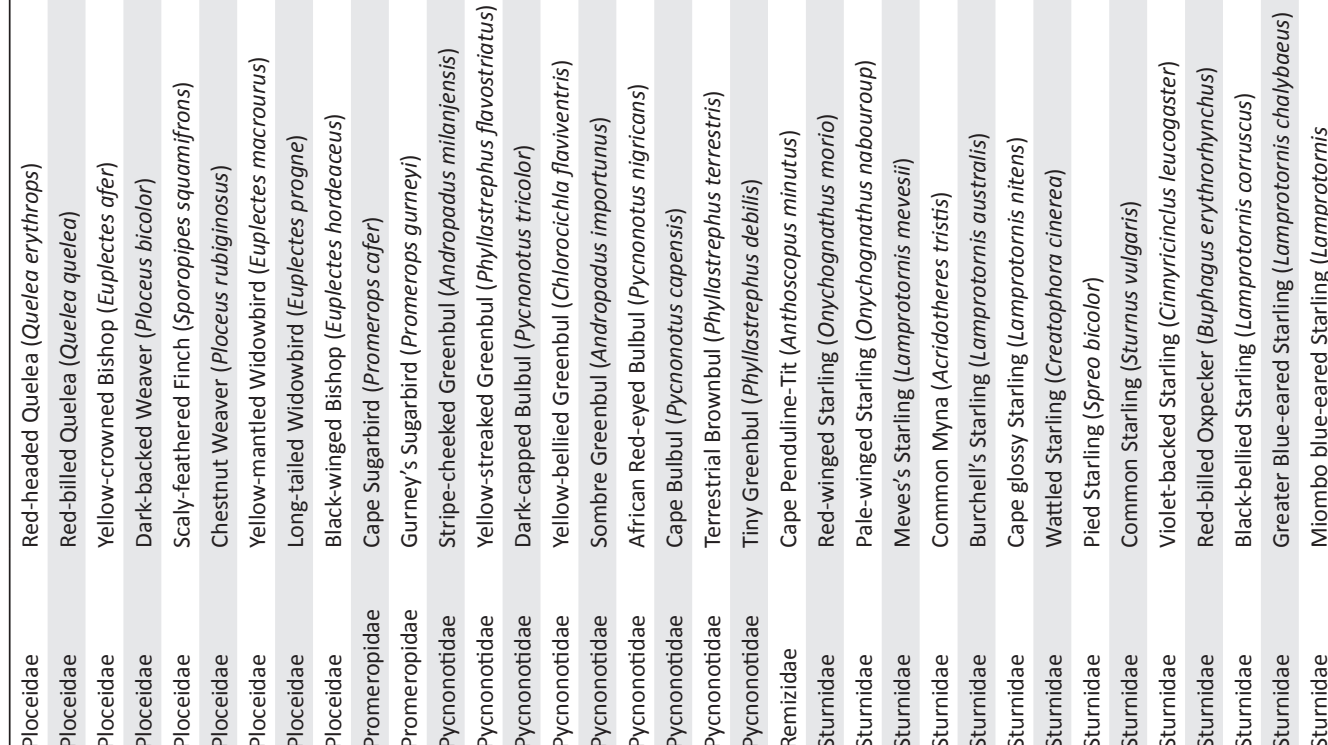

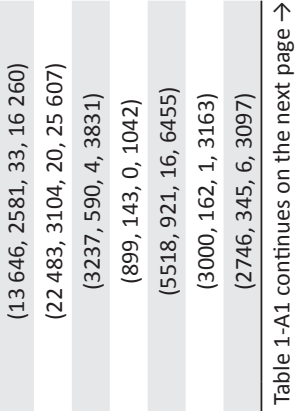

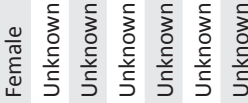

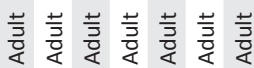

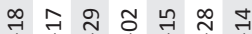
चี 岂菅岗

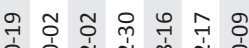
ํำ

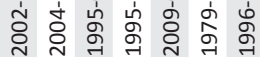

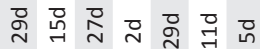
छ

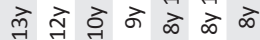

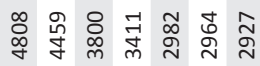

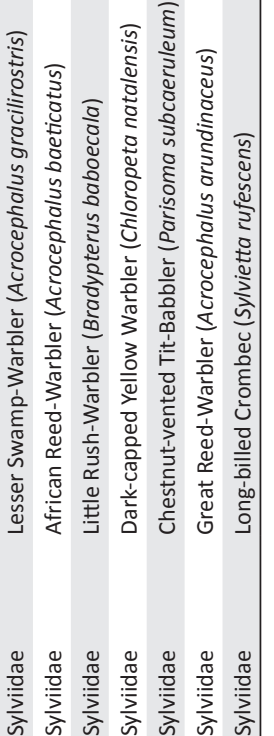


